\title{
First Record of the Parasitic Ciliate Trichodina truttae Mueller, 1937 on Chum Salmon Fry (Oncorhynchus keta) from Japan
}

\author{
S. Urawa*1 and J. R. Arthur*2 \\ ${ }^{* 1}$ Hokkaido Salmon Hatchery, Fisheries Agency of Japan, 2-2 Nakanoshima, \\ Toyohira-ku, Sapporo 062, Japan \\ ${ }^{* 2}$ Maurice Lamontagne Institute, Fisheries and Oceans, P.O. Box 1000, \\ Mont-Joli, Quebec, Canada G5H $3 Z 4$
}

(Received March 4, 1991)

\begin{abstract}
The parasitic ciliate Trichodina truttae Mueller, 1937 is redescribed from silver-impregnated specimens collected from the body surface of chum salmon fry (Oncorhynchus keta) reared in five hatcheries of Hokkaido and northern Honshu, Japan. The description is supplemented by scanning electron microscopic observations. The distinguishing morphological features include its large size (body diameter $115-178 \mu \mathrm{m}$ ), high number $(10-23)$ of radial pins per denticle, and the presence of two markedly different lengths of cilia within the adoral ciliary spiral. Geographical variation was observed in the body size and number of denticles. This is the first record of $T$. truttae from Japan.
\end{abstract}

Ciliates belonging to the family Trichodinidae are common and occasionally pathogenic parasites of freshwater and marine fishes (Lom and Hoffman, 1964; Lom and Laird, 1969; Hoffman, 1978). In Japan, trichodinid infections frequently occur on cultured freshwater and marine fishes, but taxonomic and pathological studies of this group have been very few (Egusa, 1978). Although Ariake (1929) and Suzuki (1950) reported several new species of trichodinids from Japan, these descriptions were considered by Albaladejo and Arthur (1989) to be too inadequate to permit positive reidentification. The only other confirmed identifications of Trichodina from Japanese fishes are those of Ahmed (1976, 1977), who reported T. reticulata Hirschmann and Partsch, 1955 on goldfish (Carassius auratus), crucian carp (C. auratus) and color carp (Cyprinus carpio).

In 1968, high mortalities occurred among chum salmon (Oncorhynchus keta) fry reared in Ichani Hatchery, eastern Hokkaido, due to trichodinid infections (Takeda et al., 1969). Although the parasite was reported as T. domerguei (Wallengren, 1897), its identification is suspect, since it was not based on detailed morphological studies (Nagasawa et al., 1987). Several other papers also reported trichodinid ciliates from farmed salmonids in Honshu (see Nagasawa et al., 1987). Recently, we also encountered many cases of Trichodina infections among hatchery-reared salmon fry. Experimentally, the ciliate caused severe mortalities in chum salmon fry (Urawa, unpublished data).

The present study was conducted to clarify the species of trichodinid ciliate occurring on the skin of chum salmon fry in northern Japan, and consequently the ciliate was identified as Trichodina truttae Mueller, 1937. This species was originally described from the gills of hatchery-reared cutthroat trout (Oncorhynchus clarki) in Oregon (Mueller, 1937), and has been subsequently reported from various salmonids in western North America and the USSR (Davis, 1947, 1953; Bogdanova, 1963, 1967, 1977; Bogdanova and Shtein, 1963; Arthur and Margolis, 1984). Because this finding constitutes the first record of $T$. truttae from Japan, the parasite is redescribed according to Klein's (1958) dry silver-impregnation technique and scanning electron microscopy (SEM), and some aspects of its geographical variability are noted.

\section{Materials and Methods}

Trichodinids were collected from the body 


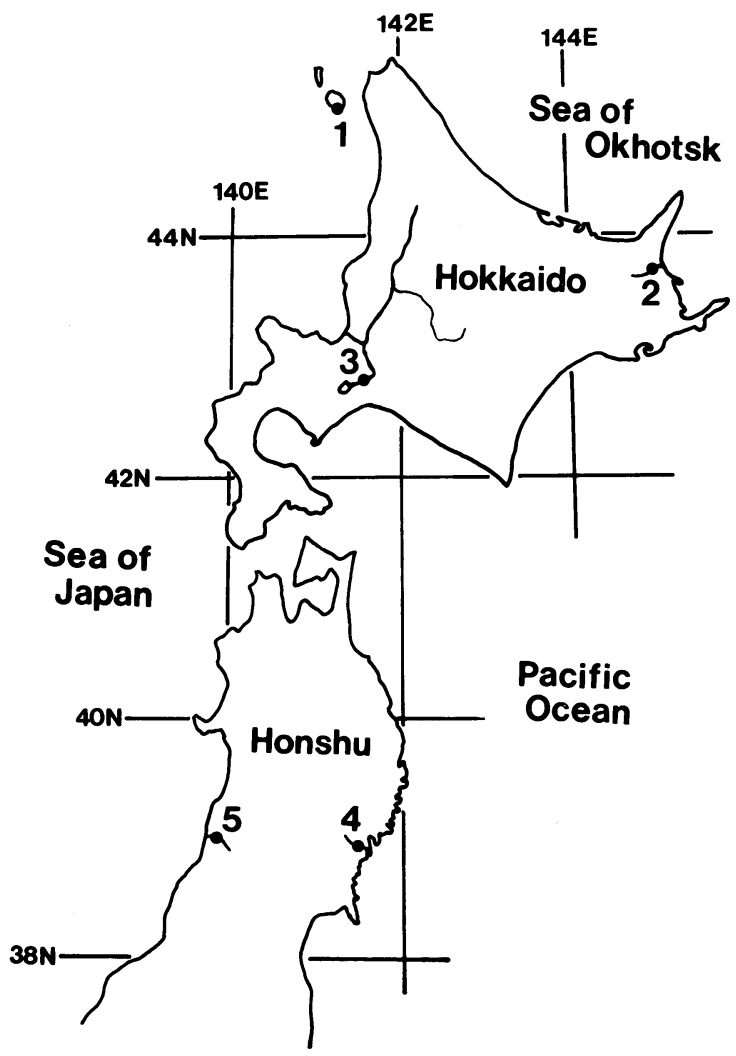

Fig. 1. Map of collection localities for Trichodina truttae infecting chum salmon fry in northern Japan. Numbers refer to hatcheries given in the legend of Fig. 10.

surface of chum salmon fry from five hatcheries in Hokkaido and northern Honshu between 1981 and 1990 (Fig. 1). Air-dried smears of living ciliates taken from the skin were prepared for light microscopical observations. Smears were immersed in a $2 \%$ solution of silver nitrate $\left(\mathrm{AgNO}_{3}\right)$ for $10 \mathrm{~min}$, and exposed to ultraviolet light for 15-20 min (Klein's dry silver-impregnation technique). In addition, some formalin preserved specimens were impregnated with silver according to Wellborn (1967). For SEM, ciliates were fixed by immersion of whole living chum salmon fry in $1 \%$ glutaraldehyde in $0.1 \mathrm{~m}$ phosphate buffer. Parasites were centrifuged and dehydrated through a graded alcohol series. The alcohol was replaced with isoamyl acetone, and the samples were dried in a Hitachi critical point drying unit, gold-coated in a sputter-coater
(Eiko), and then observed using an Akashi scanning e'ectron microscope. Terminology and methods of measurement follow the uniform specific characteristics proposed by Lom (1958) and Arthur and Lom (1984). All measurements are given in micrometers.

\section{Results}

Trichodina truttae Mueller, 1937 (Figs. 2-9)

Host: chum salmon fry (Oncorhynchus keta).

Site of infection: Body surface.

Localities: Asahi Hatchery, Rishiri Island, northern Hokkaido; Chitose Hatchery, western Hokkaido; Ichani Hatchery, eastern Hokkaido; Ohkawa Hatchery, Miyagi Prefecture, Pacific coast of northern Honshu; Gakko Hatchery, Yamagata Prefecture, Japan Sea coast of northern Honshu.

Deposition of specimens: One slide including silver-impregnated specimens from chum salmon fry from Asahi Hatchery has been deposited in the National Science Museum, Tokyo (NSMTPr. 165).

\section{Description}

The following description is based mainly on silver-impregnated ciliates collected from Asahi and Chitose Hatcheries (Table 1), supplemented by SEM observations.

A relatively large trichodinid with a discshaped body (Fig. 6), 114.7-177.5 in diameter. Adhesive disc cup-shaped, 81.1-125.0 in diameter, surrounded by a wide border membrane, 6.5-12.0 in width. Adoral ciliary complex consisting of three distinct ciliary bands: basal ciliary ring, locomotor ciliary wreath, and marginal ciliary ring (Figs. 6-8). Center of adhesive disc dark and uniformly granular in silver-impregnated specimens. Denticulate ring 45.3-75.0 in diameter, consisting of 24-31 denticles (Figs. 2 and 3). Span of denticle 24.5-35.5; length 12.8-20.0. Blade of denticle acutely falciform with highly concave anterior border and sharply angled posterior margin (Fig. 4). Blade joining central portion of denticle posterior to median axis of thorn. Length of blade 8.8-14.0. Central part thick, 4.5-8.5 in width, its external portion 

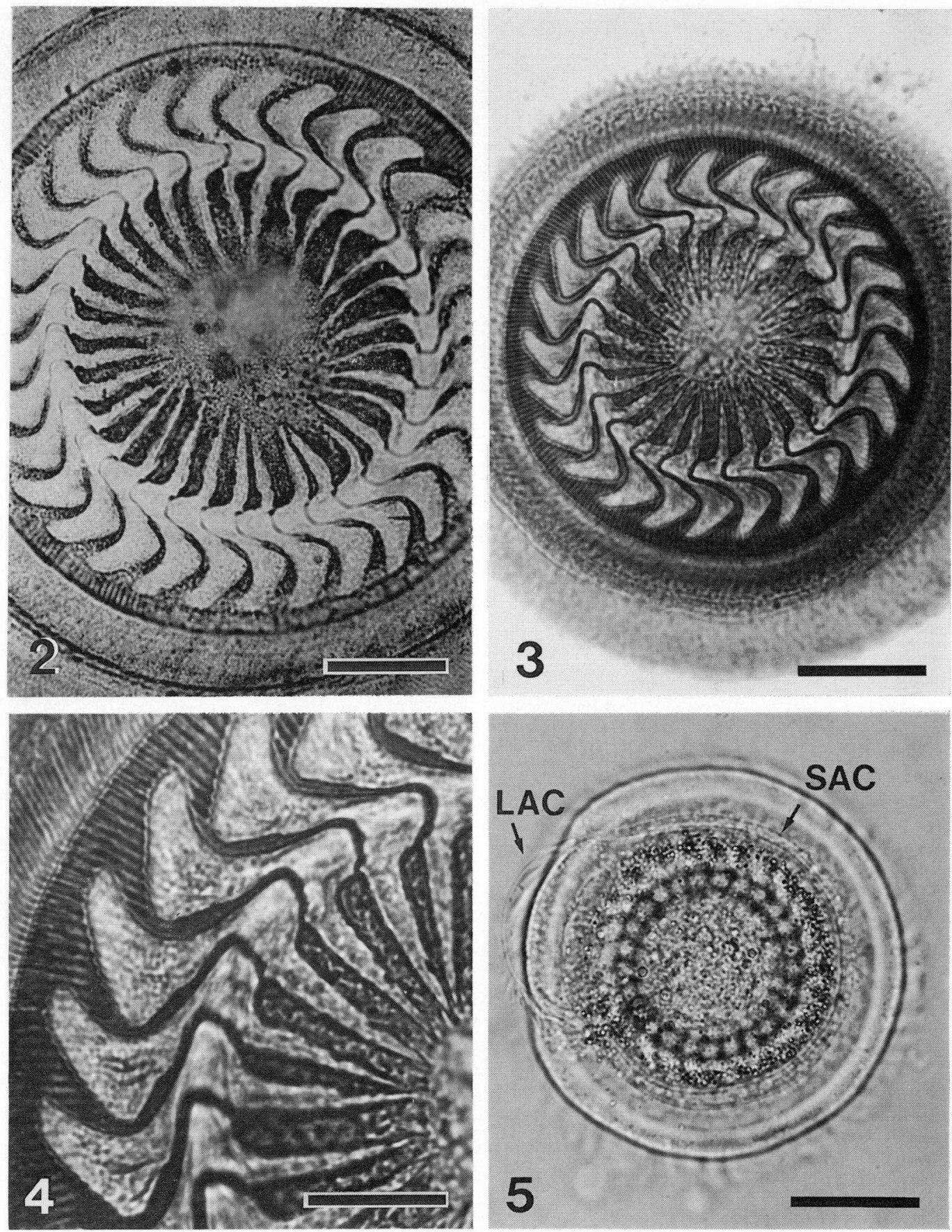

Figs. 2-5. Photomicrographs of Trichodina truttae from chum salmon fry. 2, Adhesive disc of silver-impregnated specimen collected from Asahi Hatchery. Bar $=20 \mu \mathrm{m}$. 3, Adhesive disc of silver-impregnated specimen from Chitose Hatchery. Bar $=25 \mu \mathrm{m}$. 4, Detail of adhesive disc in Fig. 3, showing radial pins, which appear as pairs in this specimen. Bar $=10 \mu \mathrm{m}$. 5, Oral view of fresh specimen from Chitose Hatchery, showing adoral ciliary spiral. Bar $=40 \mu \mathrm{m}$. LAC, long adoral cilia; SAC, short adoral cilia. 

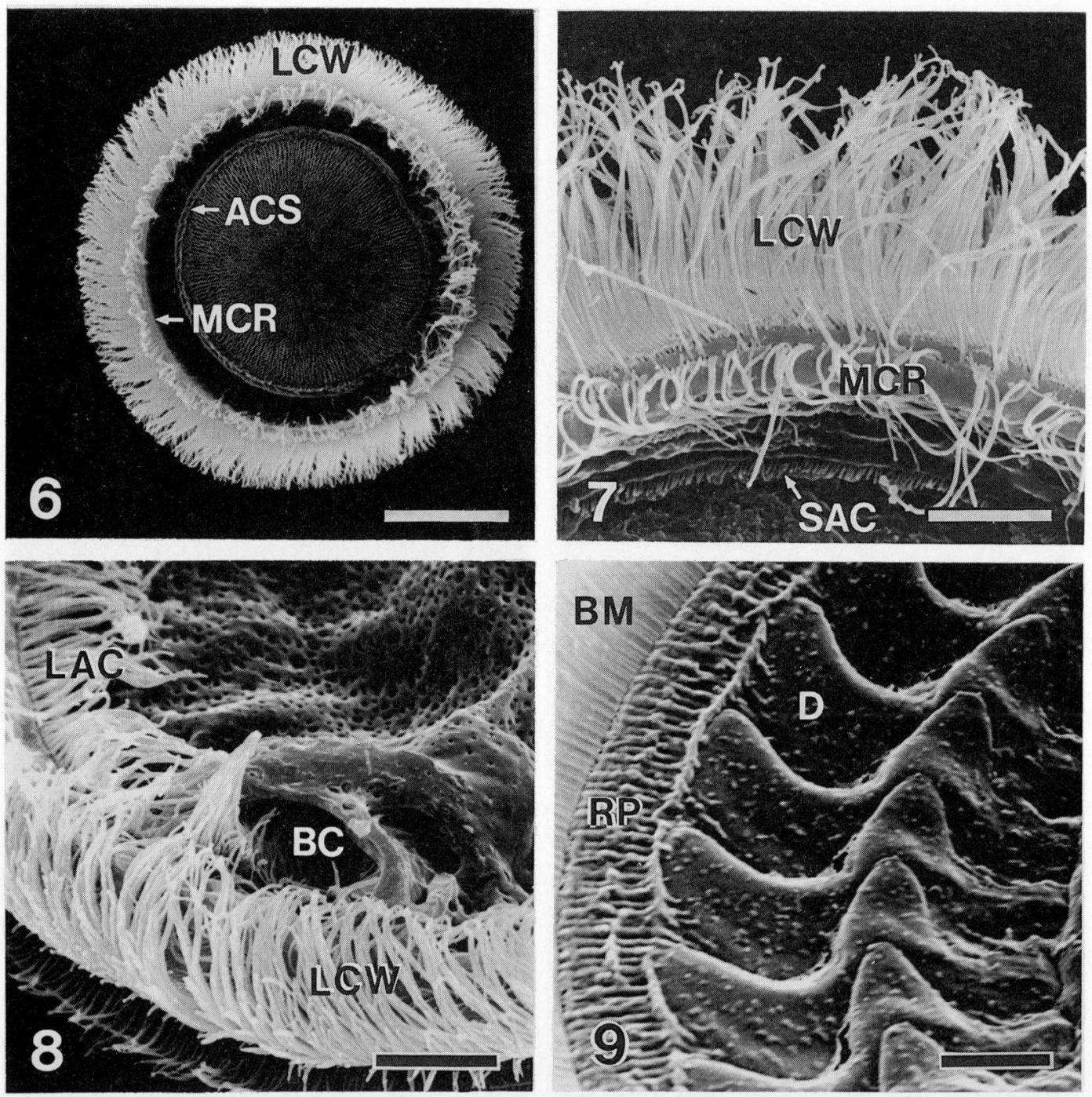

Figs. 6-9. SEM photomicrographs of Trichodina truttae from chum salmon fry reared in Chitose Hatchery. 6, Oral view of entire specimen. Bar $=35 \mu \mathrm{m} . \quad 7$, Enlargement of oral surface showing short adoral cilia. Bar $=7 \mu \mathrm{m}$. 8, Enlargement of oral surface showing long adoral cilia and buccal cavity. Bar $=8 \mu \mathrm{m}$. 9, Adhesive disc showing radial pins and denticles. Note the low number of radial pins per denticle (about 12) indicative of a recently divided specimen. Bar $=5 \mu \mathrm{m}$. ACS, adoral ciliary spiral; BC, buccal cavity; BM, border membrane; D, denticle; LAC, long adoral cilia; LCW, locomotor ciliary wreath; MCR, marginal ciliary ring; RP, radial pins; SAC, short adoral cilia.

cylindrical. Thorn thickened at base, tapering gradually to a sharp point. Length of thorn 10.4-16.0. Number of radial pins per denticle 10-23 (Figs. 4 and 9). Adoral ciliature forming a spiral of about $450^{\circ}$ (Fig. 5). The majority of cilia comprising the adoral ciliary spiral short
(Fig. 7), only final area near buccal cavity comprised of long cilia (Fig. 8). Macronucleus Ushaped, about 80 in diameter.

\section{Geographical Comparison}

Fig. 10 compares variation in parasite size 
Table 1. Comparison of morphometrics of Trichodina truttae from salmonids in Japan and Canada. Measurements are given in micrometers, and are based on silverimpregnated specimens

\begin{tabular}{|c|c|c|c|}
\hline $\begin{array}{l}\text { Source } \\
\text { Host } \\
\text { Site } \\
\text { Locality }\end{array}$ & $\begin{array}{l}\text { Present study } \\
\text { Oncorhynchus keta } \\
\text { Body surface } \\
\text { Asahi Hatchery, } \\
\text { Rishiri Island, } \\
\text { Hokkaido, Japan } \\
\qquad(n=25)\end{array}$ & $\begin{array}{c}\text { Present study } \\
\text { O. keta } \\
\text { Body surface } \\
\text { Chitose Hatchery, } \\
\text { Hokkaido, Japan } \\
\qquad(n=21)\end{array}$ & $\begin{array}{c}\text { Arthur \& Margolis (1984) } \\
\text { O. kisutch } \\
\text { Body surface } \\
\text { Quinsam Hatchery, } \\
\text { Vancouver Island, } \\
\text { B.C., Canada } \\
(n=25)\end{array}$ \\
\hline $\begin{array}{l}\text { Diameter of: } \\
\text { body }\end{array}$ & $\begin{array}{c}125.0-177.5 \\
\left(144.7 \pm 14.2^{*}\right)\end{array}$ & $\begin{array}{c}114.7-143.9 \\
(125.5 \pm 9.4)\end{array}$ & $\begin{array}{c}114.0-170.5 \\
(148.0 \pm 12.2)\end{array}$ \\
\hline adhesive disc & $\begin{array}{l}100.0-125.0 \\
(108.8 \pm 7.2)\end{array}$ & $\begin{array}{c}81.1-104.8 \\
(90.0 \pm 6.9)\end{array}$ & $\begin{array}{c}95.0-136.8 \\
(121.1 \pm 10.1)\end{array}$ \\
\hline denticulate ring & $\begin{array}{c}56.5-75.0 \\
(63.7 \pm 5.2)\end{array}$ & $\begin{array}{c}45.3-62.1 \\
(51.0 \pm 4.4)\end{array}$ & $\begin{array}{c}45.6-69.4 \\
(58.5 \pm 5.6)\end{array}$ \\
\hline $\begin{array}{c}\text { Number of: } \\
\text { denticles }\end{array}$ & $\begin{array}{c}26-31 \\
(27.2 \pm 0.9)\end{array}$ & $\begin{array}{c}24-26 \\
(24.8 \pm 0.7)\end{array}$ & $\begin{array}{c}27-31 \\
(29.5 \pm 1.0)\end{array}$ \\
\hline radial pins per denticle & $12-23$ & $10-20$ & $14-22$ \\
\hline $\begin{array}{l}\text { Dimensions of denticles: } \\
\text { length }\end{array}$ & $\begin{array}{c}14.3-19.0 \\
(16.5 \pm 1.4)\end{array}$ & $\begin{array}{c}12.8-20.0 \\
(15.4 \pm 2.2)\end{array}$ & $\begin{array}{c}14.2-22.8 \\
(19.6 \pm 1.7)\end{array}$ \\
\hline blade & $\begin{array}{c}11.0-14.0 \\
(12.1 \pm 0.9)\end{array}$ & $\begin{array}{c}8.8-11.2 \\
(9.7 \pm 0.9)\end{array}$ & $\begin{array}{c}8.6-14.7 \\
(11.7 \pm 1.4)\end{array}$ \\
\hline thorn & $\begin{array}{c}12.3-16.0 \\
(14.3 \pm 1.0)\end{array}$ & $\begin{array}{c}10.4-15.2 \\
(13.4 \pm 1.6)\end{array}$ & $\begin{array}{c}10.4-18.0 \\
(14.5 \pm 1.9)\end{array}$ \\
\hline center & $\begin{array}{l}4.5-6.2 \\
(5.5 \pm 0.5)\end{array}$ & $\begin{array}{l}6.1-8.5 \\
(7.0 \pm 0.6)\end{array}$ & $\begin{array}{l}4.9-8.6 \\
(6.8 \pm 1.0)\end{array}$ \\
\hline span & $\begin{array}{c}28.5-35.5 \\
(32.0 \pm 1.8)\end{array}$ & $\begin{array}{c}24.5-32.2 \\
(28.5 \pm 2.0)\end{array}$ & $\begin{array}{c}24.7-37.0 \\
(32.9 \pm 2.7)\end{array}$ \\
\hline $\begin{array}{l}\text { Width of border } \\
\text { membrane }\end{array}$ & $\begin{array}{c}6.5-10.0 \\
(8.4 \pm 1.0)\end{array}$ & $\begin{array}{c}7.2-12.0 \\
(9.4 \pm 1.7)\end{array}$ & $\begin{array}{c}7.6-12.4 \\
(10.4 \pm 1.4)\end{array}$ \\
\hline Adoral ciliature & about $450^{\circ}$ & about $450^{\circ}$ & $440-450^{\circ}$ \\
\hline
\end{tabular}

$*$ Mean $\pm \mathrm{SD}$.

(denticulate ring) and number of denticles among $T$. truttae populations collected from five hatcheries in northern Japan and one in Canada. The ciliates from Asahi (location 1) and Ichani (2) Hatcheries in Hokkaido are significantly larger than those from other hatcheries $(P<0.01)$. The number of denticles appears to increase with decreasing latitude in northern Japan except for specimens from Chitose Hatchery (3) where the denticle number is very small (24-26).

\section{Discussion}

Arthur and Margolis (1984) stated that the diagnostic features of $T$. truttae are its large size and large number of radial pins per denticle. This species is the largest ciliate among the more than 100 species of Trichodina described from freshwater fishes, and the number of radial pins per denticle (14-26) is the highest number reported for any member of the genus (Arthur and Margolis, 1984). In addition, their SEM observations, confirmed by the present study, note that the presence of two markedly different lengths of cilia within the adoral ciliary spiral may also be unique to $T$. truttae. Morphological features of our specimens are comparable with those of $T$. truttae as given by Arthur and Margolis (1984) (Table 1).

Many of our Japanese specimens have low numbers (8-12) of radial pins per denticle (Fig. 9). These individuals are smaller than ciliates with high denticle number (18-23). These smaller ciliates have recently undergone mi- 

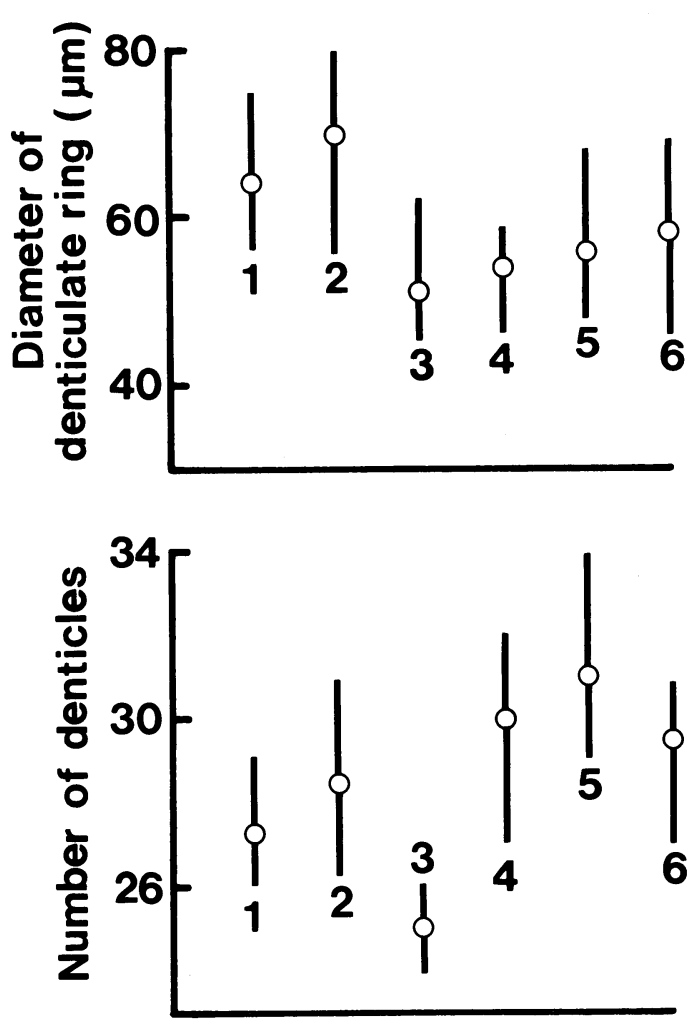

Fig. 10. Geographical variation in the diameter of the denticulate ring and number of denticles for Trichodina truttae. Each open circle represents the mean, the vertical bar represents the range. The number above or below each point is the sampling locality. 1, Asahi Hatchery $(n=25) ; 2$, Ichani Hatchery $(n=20) ; 3$, Chitose Hatchery $(n=21) ; 4$, Ohkawa Hatchery $(n=20)$; 5, Gakko Hatchery $(n=20)$; 6, Quinsam Hatchery $\left(49.3^{\prime} \mathrm{N}, 124.2^{\prime} \mathrm{W}\right)$ on Vancouver Island, B. C. $(n=25$; from Arthur and Margolis, 1984).

tosis. They have completed production of a new ring of denticles but have not yet replicated the number of radial pins.

Trichodina truttae shows geographical variability in body size and number of denticles within northern Japan (Fig. 10). The ciliates had a larger body size in Asahi and Ichani Hatcheries than in the other three hatcheries. When the host fish were collected, the rearing water temperature was about $5^{\circ} \mathrm{C}$ in the former two hatcheries, but between: $8^{\circ}$ and $10^{\circ} \mathrm{C}$ in the other hatcheries. Then, these differences in the body size may be due to differences in environment (e.g., water temperature) and/or differences in the number of recently divided ciliates among the populations. Kazubski and Pilecka-Rapacz (1981) similarly reported seasonal and interpopulational variability in the body dimensions of T. nigra Lom, 1961.

Takeda et al. (1969) recorded T. domerguei from chum salmon fry reared in Ichani Hatchery without providing any morphological description. Takeda (1971) also reported a heavy infection of Cyclochaeta (=Trichodina) domerguei on chum salmon alevins in Nemuro Hatchery, eastern Hokkaido, and listed Sakhalin taimen (Hucho perryi) and masu salmon (Oncorhynchus masou) as experimental hosts. Although $T$. domerguei has, on one occasion (see Bogdanova and Shtein, 1963), been reported from chum salmon fry, this species is primarily a parasite of gasterosteid fishes (see Lom and Stein, 1966). Our finding of only $T$. truttae from the same hatcheries as those from which $T$. domerguei was reported by Takeda et al. (1969) and Takeda (1971) and the lack of supporting evidence to validate their identifications leads us to believe that these reports are probably referable to $T$. truttae.

\section{Acknowledgements}

The authors thank Mr. Akira Kumagai of Kesennuma Miyagi Prefectural Fisheries Experimental Station and Mr. Yutaka Kasahara of Fisheries Office, Yamagata Prefecture for providing fish samples, and Dr. Kiyokuni Muroga of Hiroshima University for valuable comments on the manuscript.

\section{References}

Ahmed, A. T. A. (1976): Trichodiniasis of goldfish and other carps. Bangladesh J. Zool., 4, 12-20.

Ahmed, A. T. A. (1977): Morphology and life history of Trichodina reticulata from goldfish and other carps. Fish Pathol., 12, 21-31.

Albaladejo, J. D. and J. R. Arthur (1989): Some trichodinids (Protozoa: Ciliophora: Peritrichida) from freshwater fishes imported into the Philippines. Asian Fish. Sci., 3, 1-25.

Ariake, B. (1929): Five new species of Trichodina. 
Annot. Zool. Jap., 12, 285-288.

Arthur, J. R. and J. Lom (1984): Trichodinid Protozoa (Ciliophora: Peritrichida) from freshwater fishes of Rybinsk Reservoir, USSR. J. Protozool., 31, 82-91.

Arthur, J. R. and L. Margolis (1984): Trichodina truttae Mueller, 1937 (Ciliophora: Peritrichida), a common pathogenic ectoparasite of cultured juvenile salmonid fishes in British Columbia: redescription and examination by scanning electron microscopy. Can J. Zool., 62, 1842-1848.

Bogdanova, E. A. (1963): The parasite fauna of salmonids from rivers of south Sakhalin. Izv. Gos. Nauchno-Issled. Inst. Ozern. Rechn. Rybn. Khoz., 54, 15-47. (In Russian with English summary.)

Bogdanova, E. A. (1967): The parasite fauna of Atlantic salmon (Salmo salar L.), chum salmon (Oncorhynchus keta W.) and pink salmon ( $O$. gorbuscha W.) in hatcheries of the Kola Peninsula. Izv. Gos. Nauchno-Issled. Inst. Ozern. Rechn. Rybn. Khoz., 63, 173-188. (In Russian with English summary.)

Bogdanova, E. A. (1977): Parasites and invasive diseases of salmonids and whitefish in hatcheries. Izv. Gos. Nauchno-Issled. Inst. Ozern. Rechn. Rybn. Khoz., 120, 1-161. (In Russian with English summary.)

Bogdanova, E. A. and G. A. Shtein (1963): Ciliates of the family Urceolariidae, parasitic on juvenile salmonids. Izv. Gos. Nauchno-Issled. Inst. Ozern. Rechn. Rybn. Khoz., 54, 48-57. (In Russian with English summary.)

Davis, H. S. (1947): Studies of the protozoan parasites of fresh-water fishes. U.S. Fish. Wildl. Serv. Fish. Bull., 41, 1-29.

Davis, H. S. (1953): Culture and diseases of game fishes. University of California Press, Berkeley and Los Angeles, $332 \mathrm{p}$.

Egusa, S. (1978): The infectious diseases of fishes. Koseisha Koseikaku, Tokyo, 554 p. (In Japanese.)

Hoffman, G. L. (1978): Ciliates of freshwater fishes. In "Parasitic protozoa. Vol. II. Intestinal flagellates, histomonads, trichomonads, amoeba, opalinids, and ciliates" (ed. by J. P. Kreier). Academic
Press, New York, San Francisco, London, pp. 583-632.

Kazubski, S. L. and M. Pilecka-Rapacz (1981): Morphological variability of Trichodina nigra Lom (Ciliata, Peritrichida), a parasite of Lucioperca lucioperca (L.) from Szczecin Gulf. Acta Protozool., 20, 103-107.

Klein, B. M. (1958): The "dry" silver method and its proper use. J. Protozool., 5, 99-103.

Lom, J. (1958): A contribution to the systematics and morphology of endoparasitic trichodinids from amphibians, with a proposal of uniform species characteristics. J. Protozool., 5, 251-263.

Lom, J. and G. L. Hoffman (1964): Geographical distribution of some species of trichodinids (Ciliate: Peritrichida) parasitic on fishes. J. Parasitol., 50, 30-35.

Lom, J. and M. Laird (1969): Parasitic protozoa from marine and euryhaline fish of Newfoundland and New Brunswick. I. Peritrichous ciliates. Can. J. Zool., 47, 1367-1380.

Lom, J. and G. A. Stein (1966): Trichodinids from sticklebacks and a remark on the taxonomic position of Trichodina domerguei (Wall.). Vestn. Cesk. Spol. Zool., 30, 39-48.

Mueller, J. F. (1937): Some species of Trichodina (Ciliata) from freshwater fishes. Trans. Am. Microsc. Soc., 56, 177-184.

Nagasawa, K., S. Urawa and T. Awakura (1987): A checklist and bibliography of parasites of salmonids of Japan. Sci. Rep. Hokkaido Salmon Hatchery, 41, 1-75.

Suzuki, S. (1950): Studies on the urceolarid ciliates of Japan. Bull. Yamagata Univ. (Nat. Sci.), 2, 181-218, $1 \mathrm{pl}$.

Takeda, K., T. Nomura, M. Harada and A. Sato (1969): Trichodina found on reared chum salmon fry. Fish and Eggs, 130, 15-18. (In Japanese.)

Takeda, S. (1971): Detection of dead eggs and treatment of Cyclochaeta. Fish and Eggs, 137, 23-27. (In Japanese.)

Wellborn, T. L. (1967): Trichodina (Ciliata: Urceolariidae) of freshwater fishes of the southeastern United States. J. Protozool., 14, 399-412. 